\title{
PROTOTYPE APLIKASI BANJAR BERBASIS ANDROID STUDIO SEBAGAI SALAH SATU PETUNJUK WISATA DI BANJARMASIN
}

\author{
Rusdina $^{1)}$, Gita Ayu Syafarina ${ }^{2)}$, Muhammad Amin ${ }^{3)}$ \\ ${ }^{1)}$ Fakultas Teknologi Informasi, Universitas Islam Kalimantan MAB Banjarmasin \\ Email : russidina@gmail.com \\ ${ }^{2)}$ Fakultas Teknologi Informasi , Universitas Islam Kalimantan MAB Banjarmasin \\ Email : gitaayusyafarina@gmail.com \\ ${ }^{3)}$ Fakultas Teknologi Informasi , Universitas Islam Kalimantan MAB Banjarmasin \\ Email :Maminbjm58@gmail.com
}

\begin{abstract}
Abstrak
Banjarmasin merupakan salah satu kota yang mempunyai beberapa tempat yang sering di kunjungi oleh wisatawan baik turis domestik ataupun Turis manca negara. Kalau dulu orang mencari petunjuk wisata melalui brosur dan peta konvensional, maka di jaman sekarang semua orang ingin sesuatu yang praktis hanya dengan melihat dari smartphone android mereka, begitu juga dengan peta wisata dibanjarmasin. Maka kami membuat Prototype Aplikasi Banjarbanar Berbasis Android Studio Sebagai Salah Satu Petunjuk Wisata Di Banjarmasin agar lebih memudahkan para wisatawan maupun warga banjarmasin mencari informasi tentang tempat yang sering dikunjungi di banjarmasin termasuk petunjuk arah ke tempat tersebut melaui maps yang tersedia. Aplikasi dibangun dengan menggunakan Android studio , Android Asset Studio untuk mendesain/mengubah gambar dan icon, Two External Libraries (ExpandableTextView,AndroidImaageSlider) untuk desain tampilan objek, dan GoogleMaps API untuk menampilkan objek peta.
\end{abstract}

Kata Kunci : Android Studio, Prototype, Wisata Banjar

\section{PENDAHULUAN}

Pariwisata menjadi aspek penting bagi suatu daerah, sebab semakin banyaknya kunjungan wisatawan bagi domestic maupun mancanegara maka pertumbuhan perekonomian suatu daerah semakin meningkat, sebaliknya jika menurunnya kunjungan para wisatawan maka akan berakibat pertumbuhan ekonomi yang melambat. Setiap daerah di Indonesia memiliki jenis pariwisatanya masing-masing salah satunya adalah Kalimantan Selatan yaitu Banjarmasin yang memiliki beberapa situs sejarah serta budaya dan religius, untuk mengenal lebih banyak informasi tempat yang ingin di datangi wisatawan maupun warga kota Banjarmasin, meskipun tidak semua orang bisa mendapatkan informasi yang lengkap dan terbaru, sehingga diperlukan adanya suatu aplikasi yang bisa mempermudah dalam pencarian data tempat maupun informasi wisata yang ada di Banjarmasin.

Selama ini wisata yang ada di Banjarmasin memiliki berbagai macam tempat yang menarik untuk di kunjungi salah satunya adalah obyek wisata budaya pasar terapung, Menurut pendapat (Poerwanto, 2006) Kebudayaan adalah proses adaptasi masyarakat terhadap lingkungannya. Sementara itu, keanekaragaman kebudayaan adalah disebabkan oleh lingkungan tempat tinggal mereka yang berbeda (environmentaldeterminism). Sedangkan Koentjaraningrat mengatakan bahwa wujud kebudayaan adalah diantaranya sebagai kompleks aktivitas kelakuan berpola dari manusia dalam masyarakat. (Rusdina, 2016)

Meskipun sudah ada beberapa situs website atau blog yang memuat informasi tentang pariwisata di Banjarmasin seperti wisata budaya,sejarah, tempat makan, dan tempat belanja namun masih belum terlalu 
lengkap, sehingga terkadang masih harus bertanya ke orang-orang sekitar untuk mencapai tujuan yang dituju. Apalagi dengan munculnya smartphone, sehingga orang tidak perlu susah lagi mencari informasi, seperti aplikasi berbentuk android yang bisa diunduh dan diinstal kapanpun dinginkan, Maka dari Itu kami mengambil sebuah judul dalam penelitian kami yaitu " Prototype Aplikasi Banjar Berbasis Android Studio Sebagai Salah Satu Petunjuk Wisata Di Banjarmasin “.

\section{LITERATUR}

Android merupakan sebuah sistem operasi untuk perangkat mobile berbasis Linux yang mencakup sistem operasi, middleware dan aplikasi (Yuniar, 2014). Android dianggap sebagai platform mobile masa depan karena memiliki ciri (Safaat, 2014)antara lain:

a. Lengkap (complete platform)

Para desainer dapat melakukan yang komprehensif ketika mereka sedang mengembangkan platform Android. Android merupakan sistem operasi yang aman dan banyak menyediakan tools dalam membangun software dan memungkinkan untuk peluang pengembangan aplikasi.

b. Terbuka (open source platform) Platform Android disediakan melalui lisensi open source. Pengembang dapat dengan bebas untuk mengembangkan aplikasi. Android sendiri menggunakan Linux Kernel 2.6.

\section{c. Bebas (free platform)}

Android adalah platform atau aplikasi yang bebas untuk develope.Tidak ada lisensi atau biaya royalti untuk pengembang pada platform Android. Tidak diperlukan biaya keanggotaan, biaya pengujian, dan kontrak. Aplikasi untuk Android dapat didistribusikan dan diperdagangkan dalam bentuk apapun. Banyak versi android yang dikebangkan sampai sekarang adalah sebagai dan versi terbarunya adalah Android versi 8.0 Oreo

Android Studio merupakan sebuah Integrated Development Environment (IDE) khusus untuk membangun aplikasi yang berjalan pada platform android.Android studio ini berbasis pada IntelliJ IDEA, sebuah IDE untuk bahasapemrograman Java. Bahasa pemrograman utama yang digunakan adalah
Java,sedangkan untuk membuat tampilan atau layout, digunakan bahasa XMLInvalid source specified..

Sistem informasi berbasis android saat ini sudah menjadi suatu kebutuhan yang penting, terlebih lagi dengan bantuan internet, wisatawan tidak perlu menunggu terlalu lama untuk mendapatkan pelayanan informasi dan lokasi pada tempat yang di tuju. Untuk mendukung hal tersebut maka dibutuhkan sebuah aplikasi untuk membantu pelayanan informasi dan petunjuk arah secara online dengan android yang sebelumnya dilakukan secara manual, dengan adanya aplikasi ini diharapkan mempermudah wisatawan untuk pergi ketempat yang di tuju. (Rusdina, 2018)

\section{METODE PENELITIAN}

Sistem informasi berbasis android saat ini sudah menjadi suatu kebutuhan yang penting, terlebih lagi dengan bantuan internet, wisatawan tidak perlu menunggu terlalu lama untuk mendapatkan pelayanan informasi dan lokasi pada tempat yang di tuju. Untuk mendukung hal tersebut maka dibutuhkan sebuah aplikasi untuk membantu pelayanan informasi dan petunjuk arah secara online dengan android yang sebelumnya dilakukan secara manual, dengan adanya aplikasi ini diharapkan mempermudah wisatawan untuk pergi ketempat yang di tuju.

Untuk penelitian ini kami menggunakan metode penelitian eksploratif . Penelitian eksploratif merupakan jenis penelitian sosial yang bertujuan untuk memberikan sedikit definisi/penjelasan mengenai sebuah konsep ataupun pola yang akan digunakan dalam penelitian (Hermawan, hal 17). Dalam penelitian eksploratif ini, peneliti memang belum memiliki gambaran tentang definisi atau konsep penelitian secara kongkkrit. Peneliti akan mengajukan pertanyaan what untuk dapat menggali informasi secara lebih jauh. Untuk Sifat dari penelitian ini yaitu kreatifitas, fleksibelitas, openess, dan semua sumber lainnya yang dianggap penting sebagai sumber informasi yang dicari .

Tujuan dari penelitian eksploratif yaitu untuk menjadikan topik penelitian lebih 
dikenal oleh masyarakat luas, dan memberikan gambaran dasar mengenai topik yang di bahas, menggeneralisasi sebuah gagasan serta mengembangkan teori yang mempunyai sifat tentatif, serta membuka kemungkinan akan diadakannya penelitian lanjutan terhadap topik yang sudah dibahas, serta menentukan teknik serta arah yang akan dipergunakan dalam penelitian berikutnya.

Adapun rancangan sistem yang akan dibangun digambarkan dengan wisatawan yang datang ke banjarmasin ingin ketempat wisata dan mengunjungi tempat wisata terdekat di sekitarnya,seperti gambar dibawah ini :

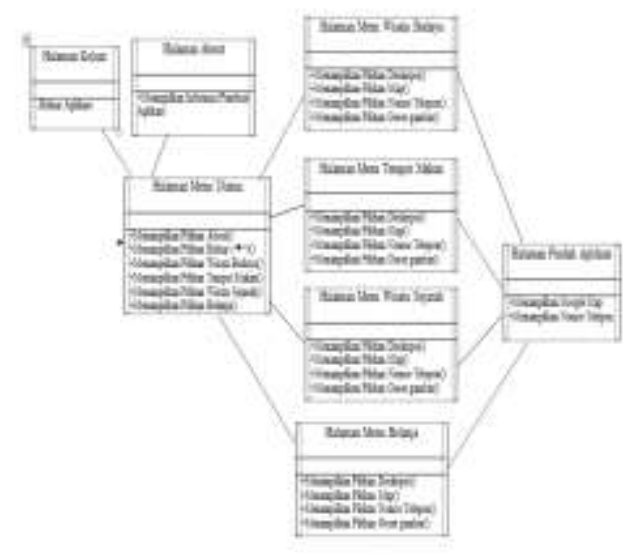

Gambar 1 Class Diagram aplikasi pemetaan dan situs sejarah dan budaya

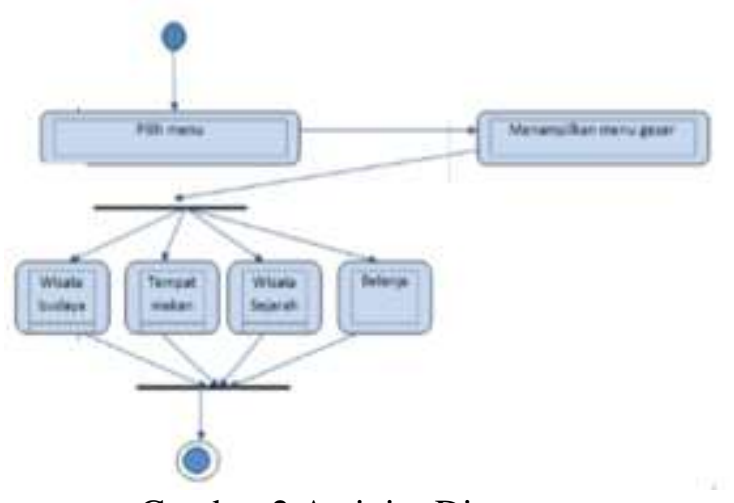

Gambar 2 Activity Diagram

\section{HASIL PENELITIAN}

Hasil Penelitian di gambarkan dalam bentuk hasil tampilan aplikasi, yaitu :

Halaman splash screen merupakan antarmuka pertama yang muncul ketika aplikasi dijalankan. Halaman ini merupakan sebuah halaman tunggu untuk masuk ke dalam halaman utama.

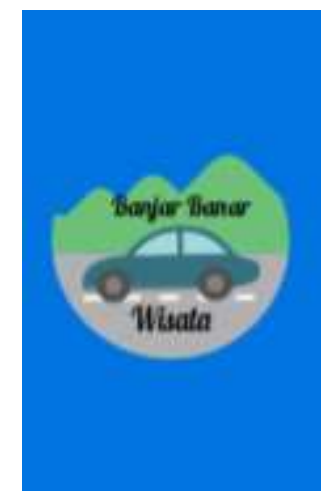

Gambar 3 Splash Screen

Setelah halaman splash screen selesai, maka program otomatis langsung masuk ke menu utama, didalam menu utama terdapat beberapa menu yang dapat di geser, ada menu wisata budaya, menu tempat makan, menu wisata sejarah, menu belanja,dan menu about.

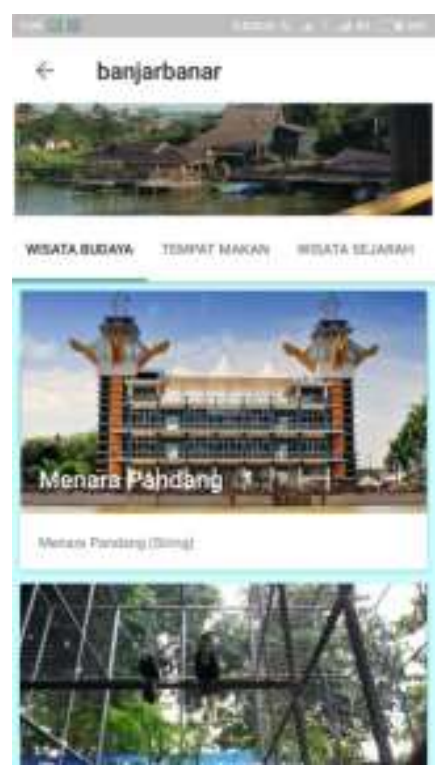

Gambar 4 Halaman Utama 
Halaman ini menampilkan wisata budaya yang di pilih dari halaman utama. Dimana wisata budaya di Banjarmasin dikenal sebagai Menara Pandang

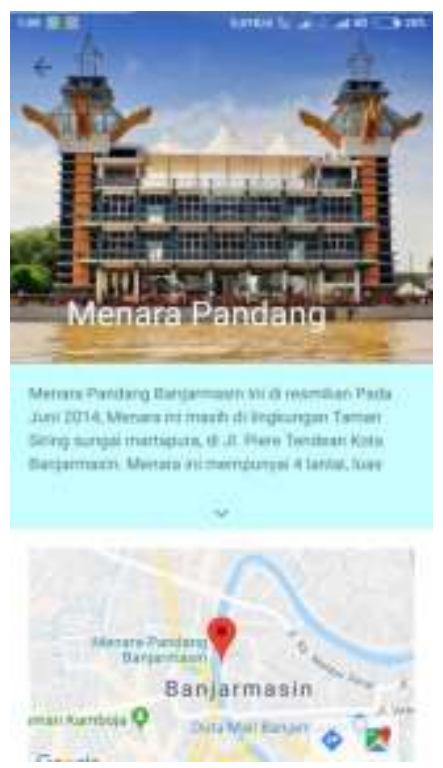

\section{Gambar 5 Halaman Menara Pandang}

Sedangkan gambar di bawah ini adalah maps setelah di tap di mana wisatawan berada menuju ke lokasi tempat tujuan yang diinginkan.

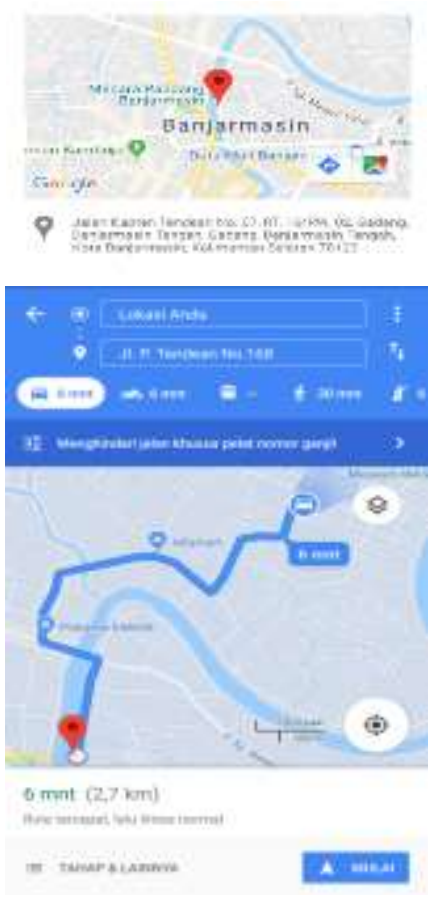

Gambar 6 Halaman Google Maps(sebelum dan sesudah)
Dalam halaman imageslider akan menampilkan tampilan tiap-tiap gambar secara otomatis. Sedangkan Dalam halaman About menampilkan informasi pembuat aplikasi.

Untuk Pengujian sistem ini dilakukan dengan cara mencoba fungsi yang di buat pada setiap Activity. Dalam pengujian sistem di aplikasi ini terdapat satu pengujian, yaitu dengan menggunakan Black Box Testing.

Tabel 1Black Box Testing

\begin{tabular}{|c|c|c|c|c|}
\hline $\begin{array}{l}\text { Tet } \\
\text { Case } \\
\text { ID }\end{array}$ & Tujuan Pengujian & Tindakn & $\begin{array}{l}\text { Hasil yang } \\
\text { diharapan }\end{array}$ & Kesimpula \\
\hline 1 & $\begin{array}{c}\text { Menunculkra } \\
\text { halaman }\end{array}$ & $\begin{array}{l}\text { Teq yang } \\
\text { dipilits }\end{array}$ & $\begin{array}{l}\text { Sesaai yang } \\
\text { diharapkan }\end{array}$ & $\begin{array}{l}\text { [v] Ditarim } \\
\text { [ ] Ditolak }\end{array}$ \\
\hline 2 & $\begin{array}{c}\text { Memunculkan } \\
\text { TeaVieu }\end{array}$ & $\begin{array}{l}\text { Isp yang } \\
\text { dipilith }\end{array}$ & $\begin{array}{l}\text { Sesuad yang } \\
\text { dihariplan }\end{array}$ & $\begin{array}{l}\text { [v] Ditarim: } \\
\text { [ ] Ditelak }\end{array}$ \\
\hline 3 & $\begin{array}{c}\text { Menusiculkatio } \\
\text { ogle Mhps }\end{array}$ & $\begin{array}{l}\text { Top yane } \\
\text { dipilib }\end{array}$ & $\begin{array}{l}\text { Sevuai yang } \\
\text { diharapkan }\end{array}$ & $\begin{array}{l}\text { [v] Diterim } \\
\text { [ ] Ditolak }\end{array}$ \\
\hline 4 & $\begin{array}{l}\text { Memusculkae } \\
\text { Tdepon }\end{array}$ & $\begin{array}{l}\text { Tapyang } \\
\text { dipilits }\end{array}$ & $\begin{array}{l}\text { 5esuad yang } \\
\text { diharapkan }\end{array}$ & $\begin{array}{l}\text { [v] Ditaim: } \\
\text { U J Ditolak }\end{array}$ \\
\hline 5 & $\begin{array}{c}\text { Memumculkan } \\
\text { Youtube }\end{array}$ & $\begin{array}{c}\text { Inp yane } \\
\text { dipitib }\end{array}$ & Tidak sesua & $\begin{array}{l}\text { I ] Diterim: } \\
\text { [v] Ditolak }\end{array}$ \\
\hline 0 & $\begin{array}{l}\text { Mlenuniculkan } \\
\text { lmagestlider }\end{array}$ & $\begin{array}{l}\text { Tapyane } \\
\text { dipilits }\end{array}$ & $\begin{array}{l}\text { Seraal yane } \\
\text { diharapkan }\end{array}$ & $\begin{array}{l}\text { [v] Ditatm: } \\
\text { [ ] Ditolak }\end{array}$ \\
\hline
\end{tabular}

\section{KESIMPULAN}

Berdasarkan hasil penelitian yang di lakukan maka dapat disimpulkan bahwa :

1. Aplikasi Andriod ini memberikan kemudahan dalam hal pencarian tempat wisata bagi turis, pelancong ataupun wisatawan yang ingin berkunjung ke tempat wisata Banjarmasin maupun hanya sekedar mengetahui informasi pariwisata yang ada di Banjarmasin

2. Dengan adanya dukungan Google Maps bisa mengarahkan dan menujukkan lokasi wisata secara cepat serta memungkinkan menunjukkan tempat wisata terdekat dari lokasi wisatawan berada.

\section{REFERENSI}

[1]A. Rina., 2016. Implementasi Peningkatan Citra X-Ray Menggunakan Komparasi Clip Limit Clahe Dengan Global Threshold 
Metode Graythresh. Technologia, 7(Vol 7, No 4 (2016)), pp. 21-27.

[2] Hermawan, A., hal 17. Penelitian Bisnis-Paradigma Kuantitatif. 1 penyunt. Jakarta: PT.Grasindo.

[3] Hutahaean, J., 2014. Konsep Sistem Informasi. Yogyakarta: CV. Budi Utama.

[4] Rina Alfah, T. V. R., 2018. Sistem EPrescribing Dan BARCODE SYSTEM Untuk Resep Obat Di Rumah Sakit. Jurnal Teknologi Informasi Universitas Lambung Mangkurat (JTIULM), 03(Vol. 3 No. 2 (2018)), pp. 59-70.

[5] Rusdina, 2016. Perancangan Dan Implementasi Aplikasi Administrasi Laundry Kiloan Dengan Menggunakan Visual Basic. Technologia, 7(vol .7 no.4 2016), pp. 230-236.

[6] Rusdina, 2018. Perancangan Aplikasi Rawat Inap Di Klinik Bidan Sumirat, Pengaron Kalimantan Selatan. Balikpapan, Seminar Nasional Teknologi Informasi, Komunikasi Dan Administrasi (Seminastika) Universitas Mulia Balikpapan.

[7] Safaat, N., 2014. Pemograman Aplikasi Mobile Smartphone dan Tablet. Bandung: Penerbit Informatika.

[8] Syamsu Rizal, E. R. A. I., 2013. Pengembangan Aplikasi Pencarian Lokasi Objek Wisata Terdekat Di Kabupaten Garut Berbasis Android. Sekolah Tinggi Teknologi Garut.

[9] Yuniar, S., 2014. Semua Bisa Menjadi Programmer Android. jakarta: Elex Media Komputindo. 